\title{
PENGARUH LIKUIDITAS (QUICK RATIO) DAN PERPUTARAN MODAL KERJA TERHADAP RETURN ON ASSET (Studi Kasus pada Perusahaan Sub Sektor Logam yang Terdaftar di Bursa Efek Indonesia Periode 2011-2015)
}

\author{
Utami Prihati Ning Tias ${ }^{1}$, Arni Purwanti ${ }^{2}$, Surtikanti ${ }^{3}$ \\ 1,2,3 Universitas Komputer Indonesia \\ purwantiarni@ymail.com², kanti_haidar@yahoo.com³
}

\begin{abstract}
ABSTRAK
Perolehan keuntungan maksimal atau laba yang sebesar-besarnya adalah salah satu tujuan didirikannya suatu perusahaan. Pada setiap kegiatan perusahaan ada unsur-unsur yang menimbulkan sebab akibat naik atau turunnya kemampuan perusahaan dalam menghasilkan laba, dan hal tersebut dapat dilihat dari beberapa faktor yang diindikasikan berpengaruh dalam naik atau turunnya kemampuan perusahaan dalam menghasilkan laba seperti, Likuiditas (Quick Ratio) dan Perputaran Modal Kerja. Penelitian ini dilakukan dengan tujuan untuk mengetahui pengaruh Likuiditas (Quick Ratio) dan Perputaran Modal Kerja terhadap Return on Asset pada Perusahaan Sub Sektor Logam Yang Terdaftar Di Bursa Efek Indonesia. Pengujian pada penelitian ini dilakukan dengan menggunakan bantuan software SPSS Versi 16.0. Metode analisis yang digunakan adalah analisis deskriptif dan verifikatif dengan pendekatan kuantitatif. Populasi dalam penelitian ini sebanyak 7 perusahaan Sub Sektor Logam yang terdaftar di Bursa Efek Indonesia periode penelitian 2011-2015. Sampel menggunakan metode purposive sampling dengan kriteriakriteria tertentu. Metode analisis yang digunakan adalah analisis regresi linier berganda. Hasil pengujian hipotesis dalam penelitian ini menunjukkan bahwa (1) Likuiditas (Quick Ratio) memiliki pengaruh negatif dan signifikan pada Return on Asset (2) Perputaran Modal Kerja memiliki pengaruh positif dan signifikan pada Return on Asset di perusahaan manufaktur sub sektor makanan dan minuman yang terdaftar di Bursa Efek Indonesia periode penelitian 2011-2015.
\end{abstract}

Kata Kunci : Likuiditas (Quick Ratio), Perputaran Modal Kerja dan Return on Asset

\begin{abstract}
Obtaining maximum profit is one of the purposes of the establishment of a company. In every company actions or activities there are elements which give the cause and effect of the company in generating profits, and this can be seen from some of the factors indicated in rise or decline in the company's ability in producing such profits, liquidity (Quick Ratio) and Working Capital Turnover. The purpose of this research is to acknowledge the influence of liquidity (Quick Ratio) and Working Capital Turnover against Return on Asset on metal sub sector companies enlisted in Indonesia Stock Exchange. In this study, the test of mediation variables is also done by using SPSS v. 16.0. The methods used were descriptive and verificative analysis. The population in this research are 7 metal sub sectors companies enlisted in Indonesia stock exchange period 2011-2015. Sampling method was using purposive sampling with specific criteria. Analysis
\end{abstract}


method was using multi-linear regression analysis. The results of hypothesis testing in this study suggest that (1) Liquidity (Quick Ratio) has negative and significant influence on Return on Asset (2) Turnover of working capital has positive and significant effect on Return on Asset in the metal manufacturing sub sector company enlisted on the Indonesia Stock Exchange period 2011-2015.

Keywords : Liquidity (Quick Ratio), Working Capital Turnover and Return On Asset

\section{PENDAHULUAN}

\subsection{Latar Belakang}

Perusahaan didirikan karena memiliki tujuan, salah satu tujuan akhir yang ingin dicapai suatu perusahaan yang terpenting adalah memperoleh laba atau keuntungan yang maksimal, disamping hal lainnya. Profitabilitas merupakan rasio yang digunakan untuk menilai suatu perusahaan di dalam mencari keuntungan. Rasio ini juga mencerminkan tingkat efektivitas manajemen perusahaan yang dapat dilihat dari laba yang dihasilkan melalui penjualan dan investasi (Kasmir, 2016:114). Profitabilitas suatu perusahaan menunjukkan perbandingan antara laba dengan aktiva atau modal yang menghasilkan laba tersebut, dengan kata lain profitabilitas adalah kemampuan perusahaan untuk menghasilkan laba selama periode tertentu (Riyanto, 2011). Hasil pengukuran tersebut dapat dijadikan alat evaluasi kinerja manajemen selama ini, apakah mereka telah bekerja secara efektif atau tidak (Kasmir, 2016:196). Adapun alat analisis yang dapat mengukur kinerja keuangan salah satunya ROA (Return On Asset) yang dapat mengukur kinerja keuangan perusahaan dalam menghasilkan laba (Tambunan, 2008). Return On Asset (ROA) sebagai salah satu rasio profitabilitas yang mampu merefleksikan seberapa banyak perusahaan telah memperoleh hasil atas sumberdaya keuangan yang ditanamkan pada perusahaan (Riyanto, 2011).

Untuk menghasilkan laba yang maksimal dan perusahaan dapat mempertahankan kelangsungan hidup perusahaannya, perusahaan membutuhkan dana atau modal. Dana perusahaan bisa berasal dari sumber dana internal (internal fund) dan sumber dana eksternal (eksternal fund). Sumber dana internal perusahaan merupakan sumber dana yang berasal dari dalam perusahaan seperti laba di tahan dan akumulasi penyusutan. Sedangkan sumber dana eksternal perusahaan merupakan sumber dana dari luar perusahaan yaitu perolehan dari pinjaman kreditur dan investor. Sumber dana eksternal akan digunakan perusahaan sebagai pelengkap apabila dana internal kurang mencukupi (Putri Handayani:2007).

Rasio likuiditas merupakan rasio yang menggambarkan kemampuan perusahaan dalam memenuhi kewajiban jangka pendek. Fungsi lain rasio likuiditas adalah untuk menunjukkan atau mengukur kemampuan perusahaan dalam memenuhi kewajibannya yang jatuh tempo, baik kewajiban kepada pihak luar perusahaan (likuiditas badan usaha) maupun di dalam perusahaan (likuiditas perusahaan). Atau dengan kata lain, rasio likuiditas merupakan yang menunjukkan kemampuan perusahaan untuk membayar utang-utang (kewajiban) jangka pendeknya yang jatuh tempo, atau rasio untuk mengetahui kemampuan perusahaan dalam membiayai dan memenuhi kewajiban (utang) pada saat ditagih (Kasmir, 2016:110).

Salah satu rasio likuiditas yang menunjukkan kemampuan perusahaan dalam memenuhi atau membayar kewajiban atau utang lancar (utang jangka pendek) adalah rasio cepat atau quick ratio. Rasio cepat (quick ratio) atau rasio sangat lancar atau acid test ratio 
merupakan rasio yang menunjukkan kemampuan perusahaan dalam memenuhi atau membayar kewajiban atau utang lancar (utang jangka pendek) dengan aktiva lancar tanpa memperhitungkan nilai sediaan (inventory) (Kasmir, 2016:136). Artinya nilai sediaan kita abaikan, dengan cara dikurangi dari nilai total aktiva lancar. Hal ini dilakukan karena sediaan dianggap memerlukan waktu relatif lebih lama untuk diuangkan, apabila perusahaan membutuhkan dana cepat untuk membayar kewajibannya dibandingkan dengan aktiva lancar lainnya (Kasmir, 2016:137)

\subsection{Rumusan Masalah}

1. Seberapa besar pengaruh Likuiditas (Quick Ratio) terhadap Return On Asset (ROA) pada perusahaan manufaktur sub sektor logam yang terdaftar di Bursa Efek Indonesia periode 2011-2015.

2. Seberapa besar pengaruh Perputaran Modal Kerja (Working Capital Turnover) terhadap Return On Asset (ROA) pada perusahaan manufaktur sub sektor logam yang terdaftar di Bursa Efek Indonesia periode 2011-2015.

\subsection{Maksud dan Tujuan Penelitian \\ 1.3.1 Maksud Penelitian}

Maksud dari penelitian ini adalah untuk memperoleh data dan informasi dari objek penelitian yang relevan atas penelitian yang telah dilakukan, yakni untuk mengetahui seberapa besar pengaruh Likuiditas (Quick Ratio) dan Perputaran Modal Kerja (Working Capital Turnover) terhadap Return On Asset (ROA) pada perusahaan manufaktur sub sektor logam yang terdaftar di Bursa Efek Indonesia.

\subsubsection{Tujuan Penelitian}

1. Untuk mengetahui seberapa besar pengaruh Likuiditas (Quick Ratio) terhadap Return On Asset (ROA) pada perusahaan manufaktur sub sektor logam yang terdaftar di Bursa Efek Indonesia periode 2011-2015.

2. Untuk mengetahui seberapa besar pengaruh Perputaran Modal Kerja (Working Capital Turnover) terhadap Return On Asset (ROA) pada perusahaan manufaktur sub sektor logam yang terdaftar di Bursa Efek Indonesia periode 2011-2015.

\subsection{Kegunaan Penelitian \\ 1.4.1 Kegunaan Praktisi (Applied Research)}

Penelitian ini diharapkan dapat memberikan informasi serta saran kepada pihak manajemen perusahaan megenai masalah yang berkaitan dengan Likuiditas (Quick Ratio) dan Perputaran Modal Kerja (Working Capital Turnover).

\subsubsection{Kegunaan Akademis (Basic Research)}

\section{Bagi Pengembangan Ilmu}

Hasil penelitian ini diharapkan dapat memberikan informasi untuk perkembangan ilmu akuntansi keuangan yang berkaitan dengan Likuiditas (Quick Ratio), Perputaran Modal Kerja (Working Capital Turnover) dan Return On Asset (ROA).

\section{Bagi Penelitian Selanjutnya}

Menjadikan hasil peneliian ini sebagai bahan referensi serta kajian lebih lanjut mengenai masalah yang berhubungan dengan Likuiditas (Quick Ratio), Perputaran Modal Kerja (Working Capital Turnover) dan Return On 
Asset (ROA).

\section{KAJIAN PUSTAKA}

\subsection{Kajian Pustaka}

\subsubsection{Definisi Rasio Likuiditas}

Menurut Fred Weston dalam buku Kasmir (2016:129) rasio likuiditas (liquidity ratio) merupakan rasio yang menggambarkan kemampuan perusahaan dalam memenuhi kewajiban (utang) jangka pendek. Dengan kata lain, rasio likuiditas berfungsi untuk menunjukkan atau mengukur kemampuan perusahaan dalam memenuhi kewajibannya yang sudah jatuh tempo,baik kewajiban kepada pihak luar perusahaan (likuiditas badan usaha) maupun di dalam perusahaan (likuiditas perusahaan).

\subsubsection{Definisi Quick Ratio}

Jumingan (2014 : 125) berpendapat bahwa rasio untuk mengukur likuiditas adalah acid test ratio(disebut juga quick ratio atau liquidity ratio). Quick ratio dihitung dengan membandingkan kas dan quick asset di satu pihak dengan utang jangka pendek di pihak lain.

\subsubsection{Indikator Quick Ratio}

Menurut Kasmir (2016:137) rumus yang digunakan untuk mencari rasio cepat adalah sebagai berikut:

$$
\text { Quick Ratio }=\frac{\text { Aktiva Lancar }- \text { Persediaan }}{\text { Utang Lancar }}
$$

\subsubsection{Definisi Perputaran Modal Kerja}

Menurut Kasmir (2016:182) Perputaran Modal Kerja (Working Capital Turnover) merupakan salah satu rasio untuk mengukur atau menilai keefektifan modal kerja perusahaan selama periode tertentu. Artinya investasi yang dilakukan perusahaan yang dimulai dari aset kas sampai kembali menjadi kas dalam suatu periode. Untuk mengukur rasio ini, dengan membandingkan antara penjualan dengan modal kerja atau dengan modal kerja rata-rata. Apabila perputaran modal kerja rendah dapat diartikan perusahaan sedang kelebihan modal kerja. Hal ini disebabkan karena rendahnya perputaran persediaan atau piutang atau saldo kas yang terlalu besar. Demikian pula sebaliknya, jika perputaran modal kerja tinggi, mungkin disebabkan tingginya perputaran persediaan, piutang, atau saldo kas yang terlalu kecil.

\subsubsection{Indikator Perputaran Modal Kerja}

Menurut Kasmir (2016:183) Perputaran Modal Kerja dapat dihitung dengan rumus sebagai berikut :

Perputaran Modal Kerja $=\frac{\text { Penjualan bersih }}{\text { Modal kerja }}$

\subsubsection{Definisi Return on Asset}

Van Horne dan Wachowicz (2012:222) mengemukakan rasio profitabilitas terdiri atas dua jenis, yaitu rasio yang menunjukkan profitabilitas dalam kaitannya dengan penjualan dan rasio yang menunjukkan profitabilitas dalam kaitannya dengan investasi. Profitabilitas dalam hubungannya dengan penjualan terdiri atas margin laba kotor (Gross Profit Margin) dan margin laba bersih (Net Profit Margin). Profitabilitas dalam hubungannya dengan investasi terdiri atas tingkat pengembalian atas aktiva (Return On Asset) dan tingkat pengembalian atas ekuitas (Return On Equity). 


\subsubsection{Indikator Return on Asset}

Menurut Sofyan Syafri Harahap (2011:305) rumus yang digunakan untuk menghitung Return on Asset (ROA) adalah sebagai berikut :

$$
R O A=\frac{\text { Laba Bersih Setelah Pajak }}{\text { Total Aktiva }} \times 100 \%
$$

\subsection{Kerangka Pemikiran \\ 2.2.1 Pengaruh Likuiditas (Quick Ratio) Terhadap Return on Asset (ROA)}

Menurut Syamsuddin, (2011:41) Likuiditas tidak hanya berkenaan dengan keadaan keseluruhan keuangan perusahaan, tetapi juga berkaitan dengan kemampuannya untuk mengubah aktiva lancar tertentu menjadi uang kas. Bilamana rasio likuiditas (quick ratio) meningkat maka baik profitabilitas (ROA) maupun resiko yang dihadapi akan menurun (Syamsuddin, 2011:209).

Berdasarkan hasil penelitian Yunita Natalia, Ventje dan Harijanto (2014) yang menyatakan bahwa likuditas (Quick Ratio) secara simultan berpengaruh terhadap profitabilitas (Return On Asset) sedangkan secara parsial likuiditas (Quick Ratio) berpengaruh signifikan negatif terhadap profitabilitas (Return On Asset).

\subsubsection{Pengaruh Perputaran Modal Kerja Terhadap Return on Asset (ROA)}

Husnan (2002:98) berpendapat bahwa semakin pendek periode perputaran modal kerja, semakin cepat perputarannya sehingga perputaran modal kerja semakin tinggi dan perusahaan semakin efisien yang pada akhirnya profitabilitas (ROA) semakin meningkat.
Berdasarkan hasil penelitian yang dilakukan oleh Bagus Mangdahita Sariyana, Fridayana Yudiaatmaja, I Wayan Suwendra (2016) hasil penelitian menunjukkan bahwa ada pengaruh positif dan signifikan secara bersama-sama atau simultan dari perputaran modal kerja, dan likuiditas terhadap profitabilitas.

\section{$2.3 \quad$ Hipotesis}

Menurut Sugiyono (2017:159) hipotesis diartikan sebagai jawaban sementara terhadap rumusan masalah penelitian. Hipotesis dalam penelitian ini sebagai berikut:

H1 : Likuiditas (Quick Ratio) berpengaruh terhadap Return On Asset pada Perusahaan Manufaktur Sub Sektor Logam.

H2 : Perputaran Modal Kerja berpengaruh terhadap Return On Asset pada Perusahaan Manufaktur Sub Sektor Logam.

\section{METODE PENELITIAN}

\subsection{Metode Penelitian}

Menurut Sugiyono (2017:2) Metode penelitian pada dasarnya merupakan cara ilmiah untuk mendapatkan dengan tujuan dan kegunaan tertentu. Metode yang digunakan dalam penelitian ini adalah metode penelitian deskriptif verifikatif dengan pendekatan kuantitatif. Dengan menggunakan metode penelitian, maka akan diketahui hubungan yang signifikan antara variabel yang diteliti sehingga menghasilkan kesimpulan yang memperjelas gambaran mengenai objek yang diteliti.

Menurut Sugiyono (2013:86) Metode deskriptif adalah penelitian yang dilakukan terhadap variabel mandiri yaitu 
tanpa membuat perbandingan atau menghubungkan dengan variabel lainnya. Sedangkan Masyhuri (2008:45), menyatakan bahwa penelitian verifikatif yaitu memeriksa benar tidaknya apabila dijelaskan untuk menguji suatu cara dengan atau tanpa perbaikan yang telah dilaksanakan di tempat lain dengan mengatasi masalah yang serupa dengan kehidupan.

Objek penelitian menjadi sangat penting dalam sebuah penelitian, hal ini berhubungan dengan judul penelitian dan data yang diperlukan (Danang Sunyoto, 2013:19). Objek penelitian dalam penelitian ini adalah Likuiditas (Quick Ratio) sebagai variabel independen $\left(\mathrm{X}_{1}\right)$, Perputaran Modal Kerja sebagai variabel independen $\left(\mathrm{X}_{2}\right)$ dan Return On Asset sebagai variabel dependen (Y).

\subsection{Operasional Variabel}

Variabel-variabel yang diukur dalam penelitian ini yaitu :

1. Variabel Bebas/Independent (Variabel $\mathrm{X}_{1}$ dan $\mathrm{X}_{2}$ )

Menurut Sugiyono (2017:39) mendefinisikan variabel bebas adalah merupakan variabel yang mempengaruhi atau yang menjadi sebab perubahannya atau timbulnya variabel dependen (terikat). Variabel independent $\left(\mathrm{X}_{1}\right)$ dalam penelitian ini adalah Likuiditas (Quick Ratio) variabel independent $\quad\left(\mathrm{X}_{2}\right) \quad$ adalah Perputaran Modal Kerja.

2. Variabel Terikat/ Dependent (Variabel Y)

Menurut Sugiyono (2017:39) mendefinisikan variabel terikat merupakan variabel yang dipengaruhi atau yang menjadi akibat, karena adanya variabel bebas. Variabel dependent (Y) yang dimaksud dalam penelitian ini adalah Return On Asset

\subsection{Sumber Data dan Teknik Pengumpulan Data}

\subsubsection{Sumber Data}

Penelitian menggunakan data sekunder karena peneliti mengumpulkan informasi dari data yang telah diolah oleh pihak lain. Data tersebut berupa laporan keuangan tahunan pada perusahaan manufaktur sub sektor logam yang Terdaftar Di Bursa Efek Indonesia (BEI). Dimana informasi yang berhubungan mengenai Likuiditas (Quick Ratio), Perputaran Modal Kerja dan Return On Asset. Informasi tersebut diperoleh dari Indonesia Stock Exchange (www.idx.co.id).

\subsubsection{Teknik Pengumpulan Data}

Teknik pengumpulan data yang diperlukan dalam penelitian ini adalah sebagai berikut :

a. Dokumentasi

Pengumpulan data yang di peroleh merupakan data sekunder dengan cara dokumentasi. Dokumentasi dilakukan dengan menelaah dokumen-dokumen yang terdapat pada perusahaan khususnya yaitu laporan keuangan laba rugi dan laporan posisi keuangan konsolidasian pada perusahaan manufaktur sub sektor logam yang terdaftar di Bursa Efek Indonesia.

b. Penelitian Kepustakaan (Library Research)

Penelitian kepustakaan dilakukan untuk memperoleh data berupa teori-teori yang dibutuhkan peneliti dalam melakukan penelitian. Data tersebut dapat diperoleh dari buku-buku yang berhubungan dengan penelitian 
dan jurnal penelitian terdahulu sebagai media pendukung yang diperlukan dalam penelitian ini.

\subsection{Populasi, Sampel dan Tempat Serta Waktu Penelitian}

\subsubsection{Populasi}

Populasi yang digunakan peneliti adalah perusahaan manufaktur sub sektor logam yang terdaftar di Bursa Efek Indonesia (BEI) sebanyak 9 perusahaan dengan laporan keuangan tahunan dipublikasikan selama 5 periode yaitu dari tahun 2011-2015. Sehingga yang menjadi populasi dalam penelitian ini adalah 45 laporan keuangan.

\subsubsection{Penarikan Sampel}

Sampel yang diambil penulis dalam penelitian ini adalah laporan keuangan berupa neraca dan laporan laba-rugi dari perusahaan manufaktur sub sektor logam dari tahun 2011-2015 dengan pertimbangan dalam penentuan sampel yang digunakan dalam penelitian ini adalah sebagai berikut:

1. Memiliki data keuangan lengkap yang sudah diaudit selama 5 tahun berturutturut pada periode 2011-2015.

2. Laporan keuangan dinyatakan wajar tanpa pengecualian (unqulified opinion) oleh auditor.

3. Laporan keuangan dalam mata uang rupiah

\subsubsection{Tempat dan Waktu Penelitian}

Untuk memperoleh data dan informasi yang dibutuhkan dalam penyusunan penelitian ini, penulis melakukan penelitian yang terkait dengan data laporan keuangan perusahaan manufaktur sub sektor logam yang terdaftar di Bursa Efek Indonesia periode 2011-2015. Pengambilan data diperoleh melalui Indonesian Stock Exchange (IDX) Kota Bandung yang beralamat di Jl. PH.
H. Mustofa No.33 telepon: (022) 20524208 Email: pipm.bandung@idxpipm.net. Dan data didapat juga melalui website Indonesian Stock Exchange (IDX) yaitu www.idx.co.id. Penelitian ini dimulai pada bulan Maret 2017.

\subsection{Metode Pengujian Data}

\subsubsection{Pengujian Asumsi Klasik}

\section{Uji Normalitas}

Uji normalitas bertujuan untuk menguji apakah dalam model regresi, variabel pengganggu atau residual memiliki distribusi normal. Ada dua cara untuk mendeteksi apakah residual berdistribusi normal atau tidak yaitu dengan analisis grafik dan uji statistik (Imam Ghozali, 2011: 110).

\section{Uji Multikolinieritas}

Menurut Husein Umar (2011:177) mendefinisikan uji multikolinieritas adalah untuk mengetahui apakah pada model regresi ditemukan adanya korelasi antara variabel independen.

\section{Uji Autokorelasi}

Menurut Husein Umar (2014:182) mendefinisikan uji autokorelasi adalah dilakukan untuk mengetahui apakah dalam sebuah model regresi linier terdapat hubungan yang kuat baik positif maupun negatif antar data yang ada pada variabel-variabel penelitian.

4. Uji Heteroskedastisitas

Menurut Husein Umar (2014:179) mendefinisikan uji heteroskedastisitas adalah dilakukan untuk mengetahui apakah dalam sebuah model regresi terjadi ketidaksamaan varians dari residual suatu pengamatan ke pengamatan lain. 
Pengaruh Likuiditas (Quick Ratio) Dan Perputaran Modal Kerja Terhadap Return On Asset (Studi Kasus pada Perusahaan Sub Sektor Logam yang Terdaftar di Bursa Efek Indonesia Periode 20112015) (Utami Prihati Ning Tias, Arni Purwanti, Surtikanti )

\subsection{Metode Analisis Data}

1. Analisis Kualitatif

2. Analisis Kuantitatif

- $\quad$ Analisis Regresi Linier Berganda

- $\quad$ Analisis Korelasi

- $\quad$ Koefisien Determinasi

\subsubsection{Pengujian Hipotesis}

1. $\mathrm{H}_{0} ; \beta_{1}=0$, Likuiditas (Quick Ratio) tidak berpengaruh terhadap Return On Asset pada

Perusahaan Manufaktur Sub Sektor Logam yang terdaftar di Bursa Efek Indonesia.

$\mathrm{H}_{1} ; \beta_{1} \neq 0$, Perputaran Modal Kerja berpengaruh terhadap Return On Asset pada Perusahaan Manufaktur Sub Sektor Logam yang terdaftar di Bursa Efek Indonesia..

$\mathrm{H}_{0} ; \beta_{2}=0$, Likuiditas (Quick Ratio) tidak berpengaruh terhadap Return On Asset pada Perusahaan Manufaktur Sub Sektor Logam yang terdaftar di Bursa Efek Indonesia.

$\mathrm{H}_{1} ; \beta_{2} \neq 0$, Perputaran Modal Kerja berpengaruh terhadap Return On Asset pada Perusahaan Manufaktur Sub Sektor Logam yang terdaftar di Bursa Efek Indonesia.

2. Penetepan Tingkat Signifikan

Tabel distribusi t dicari pada $\mathrm{a}=5 \%: 2$ $=2,55$ (uji 2 sisi), dengan derajat kebebasan $(\mathrm{df})=\mathrm{n}-\mathrm{k}-\mathrm{l}$

3. Uji Hipotesis uji "t”

Kriteria :
- Jika $t_{\text {hitung }} \leq \mathrm{t}_{\text {tabel }}$ maka berarti $\mathrm{H}_{0}$ diterima artinya antara variabel $\mathrm{X}$ dan $\mathrm{Y}$ tidak ada hubungannya atau tidak ada pengaruhnya.

- Jika $t_{\text {hitung }} \geq \mathrm{t}_{\text {tabel }}$ berarti $\mathrm{H}_{0}$ ditolak artinya antara variabel $\mathrm{X}$ dan $\mathrm{Y}$ ada hubungannya.

\section{HASIL PENELITIAN DAN PEMBAHASAN}

\subsection{Hasil Penelitian}

2.4.1 Analisis Deskriptif

2.4.1.1 Gambaran Likuiditas (Quick Ratio)

Definisi quick ratio menurut Kasmir (2016:137) adalah rasio yang menunjukkan kemampuan perusahaan dalam memenuhi atau membayar kewajiban atau utang lancar (utang jangka pendek) dengan aktiva lancar tanpa memperhitungkan nilai persediaan.

Berdasarkan data laporan keuangan perusahaan sub sektor logam yang terdaftar di Bursa Efek Indonesia. Pada tabel 4.1 berikut dapat dilihat kondisi Capital Adequacy Ratio yang diteliti selama tahun 2011 - 2015 :

Tabel 4.1

Gambaran Likuiditas (Quick Ratio)

Perusahaan Sub Sektor Logam yang

Terdaftar di Bursa Efek Indonesia Periode 2011-2015

\begin{tabular}{|c|c|c|c|c|c|c|}
\hline \multirow{2}{*}{ No } & \multirow{2}{*}{$\begin{array}{c}\text { Perus } \\
\text { ahaan }\end{array}$} & \multicolumn{5}{|c|}{ Tahun } \\
\cline { 3 - 7 } & 20 & $\begin{array}{c}20 \\
11\end{array}$ & $\begin{array}{c}201 \\
3\end{array}$ & $\begin{array}{c}201 \\
4\end{array}$ & 2015 \\
\hline 1 & $\begin{array}{c}\text { ALK } \\
\text { A }\end{array}$ & $\begin{array}{c}1 . \\
21\end{array}$ & $\begin{array}{c}1.4 \\
8\end{array}$ & $\begin{array}{c}1.1 \\
6\end{array}$ & 1.17 & 0,69 \\
\hline 2 & ALMI & $\begin{array}{c}0 . \\
65\end{array}$ & $\begin{array}{c}0.6 \\
4\end{array}$ & 0.5 & 0.46 & 0.42 \\
\hline 3 & $\begin{array}{c}\text { BTO } \\
\mathrm{N}\end{array}$ & $\begin{array}{c}2 . \\
71\end{array}$ & $\begin{array}{c}2.9 \\
6\end{array}$ & $\begin{array}{c}3.1 \\
7\end{array}$ & 4.68 & 3.93 \\
\hline
\end{tabular}




\begin{tabular}{|c|c|c|c|c|c|c|}
\hline 4 & GDST & $\begin{array}{l}0 . \\
89\end{array}$ & $\begin{array}{c}1.5 \\
9\end{array}$ & 2.5 & 0.95 & 0.89 \\
\hline 5 & INAI & $\begin{array}{l}0 . \\
48\end{array}$ & $\begin{array}{c}0.9 \\
2\end{array}$ & 0.6 & 0.52 & 0.71 \\
\hline 6 & JKSW & $\begin{array}{l}9 . \\
31\end{array}$ & $\begin{array}{c}4.7 \\
9\end{array}$ & $\begin{array}{c}8.8 \\
3\end{array}$ & 1.62 & 1.99 \\
\hline 7 & JPRS & $\begin{array}{l}2 . \\
34\end{array}$ & $\begin{array}{c}4.9 \\
4\end{array}$ & $\begin{array}{l}208 \\
.31\end{array}$ & $\begin{array}{c}373 . \\
55\end{array}$ & $\begin{array}{c}10.4 \\
8\end{array}$ \\
\hline \multicolumn{2}{|c|}{ Mean } & $\begin{array}{l}2 . \\
51\end{array}$ & $\begin{array}{c}2.4 \\
7\end{array}$ & $\begin{array}{l}32 . \\
15\end{array}$ & $\begin{array}{c}54.7 \\
0\end{array}$ & 2.73 \\
\hline \multicolumn{2}{|c|}{ Minimum } & $\begin{array}{l}0 . \\
48\end{array}$ & $\begin{array}{c}0.6 \\
4\end{array}$ & 0.5 & 0.46 & 0.42 \\
\hline \multicolumn{2}{|c|}{ Maximum } & $\begin{array}{l}9 . \\
31\end{array}$ & $\begin{array}{c}4.9 \\
4\end{array}$ & $\begin{array}{l}208 \\
.31\end{array}$ & $\begin{array}{c}373 . \\
55\end{array}$ & $\begin{array}{c}10.4 \\
8\end{array}$ \\
\hline
\end{tabular}

\subsubsection{Gambaran Perputaran Modal Kerja}

Perputaran modal kerja merupakan salah satu rasio untuk mengukur atau menilai keefektifan modal kerja perusahaan selama periode tertentu. Artinya investasi yang dilakukan perusahaan yang dimulai dari aset kas sampai kembali menjadi kas dalam suatu periode.

Berdasarkan data laporan keuangan perusahaan sub sektor logam yang terdaftar di Bursa Efek Indonesia. Pada tabel 4.4 berikut dapat dilihat kondisi Perputaran Modal Kerja yang diteliti selama tahun 2011 - 2015 :

Tabel 4.4

Gambaran Perputaran Modal Kerja

Perusahaan Sub Sektor Logam yang

Terdaftar di Bursa Efek Indonesia Periode 2011-2015

diolah kembali)

Dapat diketahui bahwa rata - rata nilai Likuiditas (Quick Ratio) pada perusahaan sub sektor logam yang terdaftar di Bursa Efek Indonesia memiliki trendline yang fluktuatif setiap tahunnya. Meskipun rata-rata Likuiditas (Quick Ratio) pada tahun 2012 mengalami penurunan namun pada tahun 2013 dan 2014 rata-rata Likuiditas (Quick Ratio) mengalami kenaikan yang signifikan. Naiknya nilai Likuiditas (Quick Ratio) pada perusahaan sub sektor logam dikarenakan adanya kenaikan pada aktiva lancar seperti peningkatan pada kas bersih yang diperoleh dari aktivitas operasi, peningkatan dari aktivitas investasi, piutang usaha, beban dibayar dimuka dan adanya dampak dari perubahan mata uang asing.

\begin{tabular}{|c|c|c|c|c|c|c|}
\hline \multirow{3}{*}{$\begin{array}{l}N \\
0\end{array}$} & & Peric & le 201 & $1-2015$ & & \\
\hline & \multirow{2}{*}{$\begin{array}{c}\text { Perus } \\
\text { ahaa } \\
n\end{array}$} & \multicolumn{5}{|c|}{ Tahun } \\
\hline & & 201 & $\begin{array}{c}201 \\
2\end{array}$ & $\begin{array}{c}201 \\
3\end{array}$ & $\begin{array}{c}201 \\
4\end{array}$ & $\begin{array}{c}201 \\
5\end{array}$ \\
\hline \multirow{2}{*}{1} & ALK & 17.2 & 16.0 & 23.5 & 26.5 & 718 \\
\hline & A & 3 & 9 & 1 & 7 & .26 \\
\hline \multirow{2}{*}{2} & ALM & 16.7 & 11.9 & 26.5 & 571 & 2) \\
\hline & & & & & & 3 \\
\hline \multirow{2}{*}{3} & BTO & ? 01 & 226 & 123 & 095 & 0.6 \\
\hline & $\mathrm{N}$ & 2.51 & 2.20 & 1.20 & 0.35 & 4 \\
\hline \multirow{2}{*}{4} & GDS & 469 & 351 & 244 & 6.47 & 12. \\
\hline & $\mathrm{T}$ & & & & & 4 \\
\hline \multirow{2}{*}{5} & INAI & 909 & 273 & 617 & 19.0 & 41.5 \\
\hline & & 9.09 & 2.13 & 0.17 & 3 & 1 \\
\hline \multirow[t]{2}{*}{6} & JKS & 1.39 & 1 & 0.93 & 0.95 & 2.1 \\
\hline & W & & & & & 7 \\
\hline
\end{tabular}


Pengaruh Likuiditas (Quick Ratio) Dan Perputaran Modal Kerja Terhadap Return On Asset (Studi

Kasus pada Perusahaan Sub Sektor Logam yang Terdaftar di Bursa Efek Indonesia Periode 20112015) (Utami Prihati Ning Tias, Arni Purwanti, Surtikanti )

\begin{tabular}{|c|c|c|c|c|c|c|}
\hline 7 & JPRS & 2.98 & 2.04 & 0.83 & 1.4 & $\begin{array}{c}0.7 \\
2\end{array}$ \\
\hline Mean & $\begin{array}{c}7.85 \\
857 \\
1\end{array}$ & $\begin{array}{c}5.64 \\
857 \\
1\end{array}$ & $\begin{array}{c}8.81 \\
428 \\
6\end{array}$ & $\begin{array}{c}16.0 \\
671 \\
4\end{array}$ & $\begin{array}{c}107 \\
.63 \\
9\end{array}$ \\
\hline $\begin{array}{c}\text { Minimu } \\
\mathrm{m}\end{array}$ & 1.39 & 1 & 0.83 & 0.95 & $\begin{array}{c}- \\
22.23\end{array}$ \\
\hline $\begin{array}{c}\text { Maximu } \\
\mathrm{m}\end{array}$ & $\begin{array}{c}17.2 \\
3\end{array}$ & $\begin{array}{c}16.0 \\
9\end{array}$ & $\begin{array}{c}26.5 \\
9\end{array}$ & 57.1 & $\begin{array}{c}718 \\
.26\end{array}$ \\
\hline
\end{tabular}

(Sumber : Bursa Efek Indonesia yang diolah kembali)

Dapat dilihat bahwa selama periode tahun 2011 - 2015 rata - rata Perputaran Modal Kerja perusahaan sub sektor logam yang terdaftar di Bursa Efek Indonesia cenderung fluktuatif. Pada tahun 2012 mengalami penurunan dan pada tahun selanjutnya yaitu tahun 2013 2015 mengalami peningkatan, hal tersebutdisebabkan oleh turunnya penjualan dan modal kerja perusahaan mengalami penurunan yang disebabkan oleh adanya kenaikan pada kewajiban lancar.

\subsubsection{Gambaran Return On Asset}

Return On Asset (ROA) sebagai salah satu rasio profitabilitas yang mampu merefleksikan seberapa banyak perusahaan telah memperoleh hasil atas sumberdaya keuangan yang ditanamkan pada perusahaan (Riyanto, 2011).

Berdasarkan data laporan keuangan perusahaan sub sektor logam yang terdaftar di Bursa Efek Indonesia, pada tabel berikut dapat dilihat kondisi Return on Asset yang diteliti selama tahun $2011-2015$ :
Tabel 4.7

\section{Gambaran Return On Asset Perusahaan Sub Sektor Logam yang Terdaftar di Bursa Efek Indonesia Periode 2011- 2015}

\begin{tabular}{|c|c|c|c|c|c|c|}
\hline \multirow{2}{*}{$\begin{array}{l}N \\
0\end{array}$} & \multirow{2}{*}{$\begin{array}{c}\text { Perusah } \\
\text { aan }\end{array}$} & \multicolumn{5}{|c|}{ Tahun } \\
\hline & & 2011 & $\begin{array}{c}201 \\
2\end{array}$ & 2013 & 2014 & 2015 \\
\hline 1 & ALKA & $\begin{array}{c}3.8 \\
5\end{array}$ & $\begin{array}{c}3.4 \\
6\end{array}$ & -0.13 & $\begin{array}{c}1.0 \\
8\end{array}$ & -0.81 \\
\hline 2 & ALMI & 1.8 & $\begin{array}{c}0.7 \\
41\end{array}$ & $\begin{array}{c}0.9 \\
49\end{array}$ & $\begin{array}{l}0.0 \\
61\end{array}$ & -2.44 \\
\hline 3 & BTON & $\begin{array}{l}16 . \\
12\end{array}$ & $\begin{array}{l}17 . \\
06\end{array}$ & $\begin{array}{l}14 . \\
69\end{array}$ & $\begin{array}{c}4.3 \\
8\end{array}$ & $\begin{array}{c}3.4 \\
5\end{array}$ \\
\hline 4 & GDST & $\begin{array}{l}10 . \\
19\end{array}$ & 4 & $\begin{array}{c}7.7 \\
1\end{array}$ & $\begin{array}{c}- \\
1.02\end{array}$ & -4.66 \\
\hline 5 & INAI & $\begin{array}{c}4.8 \\
4\end{array}$ & $\begin{array}{c}3.7 \\
8\end{array}$ & $\begin{array}{c}0.6 \\
5\end{array}$ & $\begin{array}{c}2.4 \\
5\end{array}$ & $\begin{array}{c}2.1 \\
5\end{array}$ \\
\hline 6 & JKSW & $\begin{array}{c}- \\
0.88\end{array}$ & -5.9 & -3.03 & $\begin{array}{c}- \\
3.17\end{array}$ & 8.7 \\
\hline 7 & JPRS & 8.6 & $\begin{array}{c}2.4 \\
1\end{array}$ & 3.99 & $\begin{array}{c}- \\
1.86\end{array}$ & -6.05 \\
\hline & Mean & $\begin{array}{c}6.3 \\
6\end{array}$ & $\begin{array}{c}3.6 \\
5\end{array}$ & $\begin{array}{c}3.5 \\
4\end{array}$ & $\begin{array}{l}0.2 \\
74\end{array}$ & -2.43 \\
\hline & Iinimum & $\begin{array}{c}- \\
0.88\end{array}$ & -5.9 & -3.03 & $\begin{array}{c}- \\
3.17\end{array}$ & $\begin{array}{c}- \\
8.7\end{array}$ \\
\hline & aximum & $\begin{array}{l}16 . \\
12\end{array}$ & $\begin{array}{l}17 . \\
06\end{array}$ & $\begin{array}{l}14 . \\
69\end{array}$ & $\begin{array}{c}4.3 \\
8\end{array}$ & $\begin{array}{c}3.4 \\
5\end{array}$ \\
\hline
\end{tabular}

(Sumber : Bursa Efek Indonesia yang diolah kembali)

Dapat dilihat bahwa rata - rata Return on Asset perusahaan sub sektor logam yang terdaftar di Bursa Efek 
Indonesia mengalami penurunan sepanjang periode penelitian yaitu rentang tahun 2012 sampai dengan 2015. Hal tersebut dikarenakan adanya kenaikan pada total aktiva dan penurunan pada laba bersih setelah pajak.

\subsubsection{Analisis Verifikatif}

1) Uji Asumsi Klasik

\section{a. Uji Normalitas}

Tabel 4.10

One-Sample Kolmogorov-Smirnov Test

\begin{tabular}{|cc|r}
\hline & & $\begin{array}{r}\text { Unstandi } \\
\text { d Resic }\end{array}$ \\
\hline \multirow{3}{*}{ Normal Parameters $^{a}$} & Mean & 33 \\
& Std. Deviation & .00000 \\
Most Extreme Differences & 4.74753 \\
& Absolute & .111 \\
& Positive & .111 \\
& Negative & $-.09:$ \\
Kolmogorov-Smirnov Z & .635 \\
Asymp. Sig. (2-tailed) & .815 \\
\hline
\end{tabular}

Sumber: Data yang diolah

Uji Normalitas terlihat bahwa nilai

Sig. pada kolom Kolmogorov-

Smirnov yang diperoleh nilai masing - masing variabel bebas (Likuiditas (Quick Ratio) dan Perputaran Modal Kerja) lebih besar dari 0,05 yakni 0,815 yang menunjukkan bahwa data yang digunakan berdistribusi secara normal, sehingga asumsi normalitas data terpenuhi.

\section{b. Uji Multikolinieritas}

\section{Tabel 4.11}

Pengujian Multikolinearitas

Pengujian Multikolinearitas Coefficients $^{\mathrm{a}}$

\begin{tabular}{|ll|r|}
\hline \multirow{2}{*}{ Model } & \multicolumn{2}{|c}{ Collinearity } \\
\cline { 3 - 3 } & \multicolumn{2}{|c|}{ Tolerance } \\
\hline 1 & Quick Ratio & .921 \\
& Perputaran Modal Kerja & .92 \\
\hline
\end{tabular}

a. Dependent Variable: Return On Asset

Sumber: Data yang telah diolah

hasil pengujian dari data yang disajikan pada tabel di atas terlihat bahwa nilai tolerance yang diperoleh kedua variabel bebas masing - masing sebesar 0,920 > 0,1 dan Variance Inflation Factor (VIF) kurang dari 10 dengan nilai VIF masing - masing variabel sebesar 1.087. Hal ini menandakan bahwa kedua variabel bebas yang digunakan tidak memiliki masalah multikolinieritas.

\section{c. Uji Heteroskedastisitas}

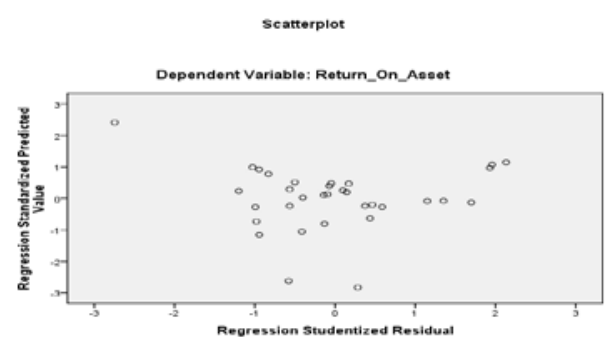

\section{Gambar 4.5}

\section{Grafik Scatterplot}

Pada gambar grafik scatterplot di atas, terlihat pada gambar diatas bahwa titik - titik yang diperoleh menyebar diatas angka nol dan dibawah angka nol pada sumbu Y tanpa membentuk pola yang teratur, maka dapat ditarik kesimpulan bahwa tidak terdapat heteroskedastisitas dalam model regresi yang digunakan atau dengan kata lain varians residual bersifat homokedastisitas. Berdasarkan keempat hasil pengujian asumsi klasik diatas, diketahui bahwa tidak terdapat pelanggaran asumsi klasik sehingga analisis regresi linier berganda dapat digunakan.

\section{d. Uji Autokorelasi}

\section{Tabel 4.12}

\section{Pengujian Autokorelasi}

\begin{tabular}{|l|c|r|r|r|r|}
\hline Model & $\mathrm{R}$ & $\mathrm{R}$ Square & $\begin{array}{c}\text { Adjusted R } \\
\text { Square }\end{array}$ & $\begin{array}{c}\text { Std. Error of } \\
\text { the Estimate }\end{array}$ & Durbin-Watson \\
\hline 1 & $.580^{\mathrm{a}}$ & .337 & .292 & 4.9032360 & .993 \\
\hline
\end{tabular}
a. Predictors: (Constant), Perputaran_Modal_Kerja, Quick_Ratio
b. Dependent Variable: Return_On_Asset


Sumber: Data yang diolah

menunjukkan bahwa nilai Durbin Watson (DW) yang diperoleh sebesar 0.993 dan berada diantara 2 dan +2 atau $-2<\mathrm{DW}<+2$. Dengan demikian dapat disimpulkan bahwa model regresi terbebas dari adanya autokorelasi, sehingga model regresi telah memenuhi salah satu syarat untuk dilakukan pengujian regresi.

\section{2) Analisis Linier Berganda}

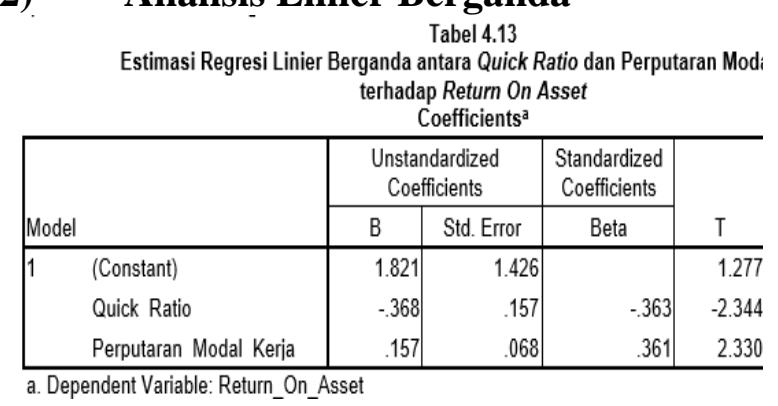

Sumber: Data yang diolah

Dari data diatas diperoleh nilai $\alpha$ sebesar 1.821, $\beta 1$ sebesar -0.368 dan $\beta 2$ sebesar 0.157 . Dengan demikian, persamaan regresi linier berganda yang akan dibentuk adalah sebagai berikut :

\section{Return On Asset $=1.821-0.368$} (Quick Ratio) + 0.157 (Perputaran Modal Kerja)

Dari hasil persamaan regresi linier berganda tersebut masing _ masing variabel dapat diinterpretasikan sebagai berikut :

a. Nilai konstanta sebesar 1.821, menunjukan besarnya Return On Asset, jika Quick Ratio dan Perputaran Modal Kerja bernilai 0.

b. Koefisien regresi untuk Quick Ratio sebesar $0.368 \mathrm{X}_{1}$. Artinya setiap terjadi peningkatan 1 satuan pada Quick Ratio dan Perputaran Modal Kerja bernilai konstan, maka diprediksikan Return On Asset pada perusahaan sub sektor logam akan menurun sebesar 0.368 .

c. Koefisien regresi untuk Perputaran Modal Kerja sebesar 0.157 $\mathrm{X}_{2}$ dan bertanda positif, artinya setiap terjadi peningkatan 1 satuan pada Perputaran Modal Kerja dan Quick Ratio bernilai konstan, diprediksikan mampu meningkatkan Return On Asset pada perusahaan sub sektor logam sebesar 0.157.

\section{3) Analisis Korelasi}

\begin{tabular}{|c|c|c|c|}
\hline Koefisien Korelasi Parsi & $\begin{array}{l}\text { Tabel } 4.14 \\
\text { antara Quick Ratio Terhe } \\
\text { Correlations }\end{array}$ & Iadap Retum 0 & In Asset \\
\hline Control Variables & & \begin{tabular}{|l|} 
Quick Ratio \\
\end{tabular} & $\begin{array}{c}\text { Return_On_As } \\
\text { set }\end{array}$ \\
\hline Perputaran_Modal_Kerja Quick_Ratio & Correlation & 1.000 & .393 \\
\hline & Significance (2-talled) & & .026 \\
\hline & Df & d & 30 \\
\hline Return_On_As & Correlation & .393 & 1.000 \\
\hline & Signnificance (2-tailed) & .026 & \\
\hline & Df & 30 & 0 \\
\hline
\end{tabular}

Sumber: Data yang diolah

a. Pada tabel output SPSS di atas, terlihat bahwa nilai korelasi parsial antara Quick Ratio dengan Return On Asset adalah sebsar -0,393. Nilai korelasi bertanda negatif yang menunjukkan bahwa hubungan yang terjadi antara keduanya adalah tidak searah. Berdasarkan interpretasi koefisien korelasi, nilai sebesar -0,393 termasuk kedalam kategori hubungan yang rendah, berada dalam kelas interval antara 0,210,40 . 
Tabel 4.15

Koefisien Korelasi Parsial antara Perputaran Modal Kerja terhadap Return On Asset Correlations

\begin{tabular}{|c|c|c|c|c|}
\hline \multicolumn{3}{|c|}{ Control Variables } & \multicolumn{2}{|c|}{\begin{tabular}{|c|c} 
Perputaran_Mo & Return_On_As \\
dal Keria & set
\end{tabular}} \\
\hline \multirow[t]{6}{*}{ Quick_Ratio } & Perputaran_Modal & Correlation & 1.000 & .391 \\
\hline & & Significance (2-tailed) & & .027 \\
\hline & & df & 0 & 30 \\
\hline & Return_On_Asset & Correlation & .391 & 1.000 \\
\hline & & Significance (2-tailed) & .027 & \\
\hline & & df & 30 & \\
\hline
\end{tabular}

Sumber: Data yang diolah

b. Pada tabel output SPSS di atas, terlihat bahwa nilai korelasi parsial antara tingkat Perputaran Modal Kerja dengan Return On Asset adalah sebesar 0,391. Nilai korelasi bertanda positif yang menunjukkan bahwa hubungan yang terjadi antara keduanya adalah searah. Berdasarkan interpretasi koefisien korelasi, nilai sebesar 0,391 termasuk kedalam kategori hubungan yang rendah, berada dalam kelas interval antara $0,21-0,40$.

\section{4) Analisis Koefisien Determinasi}

a. Pengaruh variabel Quick Ratio terhadap Return on Asset

$\mathrm{Kd}=(r)^{2} \times 100 \%$

$\mathrm{Kd}=(-0,465)^{2} \times 100 \%$

$\mathrm{Kd}=21,7$

Dari hasil perhitungan diatas terlihat bahwa nilai koefisien determinasi parsial Quick Ratio terhadap Return on Asset yang diperoleh 21,7\%.Hal ini menunjukkan bahwa Capital Adequacy Ratio memberikan kontribusi pengaruh terhadap Loan to Deposit Ratio sebesar 21,7\%, sedangkan sisanya sebesar $78,4 \%$ merupakan pengaruh dari variabel Perputaran Modal Kerja dan variabel lainnya yang tidak diteliti, seperti Net ataupun Gross Profit
Margin, Total Asset Turnover (TATO), ukuran perusahaan dan lain sebagainya.

b. Pengaruh variabel NPL terhadap LDR

$\mathrm{Kd}=(r)^{2} \times 100 \%$

$\mathrm{Kd}=(0,464)^{2} \times 100 \%$

$\mathrm{Kd}=21,5 \%$

Dari hasil perhitungan diatas terlihat bahwa nilai koefisien determinasi parsial Perputaran Modal Kerja terhadap Return on Asset yang diperoleh sebesar 21,5\%. Hal ini menunjukkan bahwa Perputaran Modal Kerja memberikan kontribusi pengaruh terhadap Loan to Deposit Ratio sebesar $21,5 \%$, sedangkan sisanya sebesar $78,5 \%$ merupakan pengaruh dari variabel Likuiditas (Quick Ratio) dan variabel lainnya yang tidak diteliti.

5) Pengujian Hipotesis

a. Pengujian Hipotesis Parsial Quick Ratio terhadap Return on Asset

Tabel 4.18

Pengujian Hipotesis Parsial antara Quick Ratio terhadap Return On

Asset

\begin{tabular}{|c|c|c|c|c|c|c|}
\hline Model & thitung & ttabel 00,$5 ; 37)$ & Sig & A & Keterangan & Kesimpulan \\
\hline$X_{1} \rightarrow Y$ & $-2,34$ & 2,042 & 0,002 & 0,05 & Ho ditolak & Signifikan \\
\hline
\end{tabular}

Sumber: Data yang diolah

Dari tabel 4.18 diatas, terlihat bahwa nilai thitung yang diperoleh variabel Quick Ratio sebesar -2,34. Nilai akan dibandingkan dengan nilai ttabel pada tabel distribusi $\mathrm{t}$. dengan $\alpha=0,05, d f(33-2-1)=30$, diperoleh nilai t-tabel untuk pengujian dua pihak sebesar \pm 2.042. Dari nilai - nilai diatas terlihat bahwa nilai $t_{\text {hitung }}$ yang diperoleh $(-2,34)$, lebih besar dari ttabel $=-2,042$, sesuai dengan kriteria pengujian hipotesis bahwa H0 diterima dan H1 ditolak, artinya secara parsial Quick Ratio 
berpengaruh signifikan terhadap Return on Asset.

b. Pengujian Hipotesis Parsial Perputaran Modal Kerja terhadap Return On Asset

Tabel 4.19

\section{Pengujian Hipotesis Parsial} antara Perputaran Modal Kerja terhadap

Return On Asset

\begin{tabular}{|c|c|c|c|c|c|c|}
\hline Model & thitung & t tabel $(0,05 ; 30)$ & Sig & A & Keterangan & Kesimpulan \\
\hline $\mathrm{X}_{1 \rightarrow \mathrm{Y}}$ & 2.33 & 2.042 & 0,019 & 0,05 & Ho ditolak & Signifikan \\
\hline
\end{tabular}

Sumber: Data yang diolah

Dari tabel 4.19 diatas, terlihat bahwa nilai thitung yang diperoleh variabel Perputaran Modal Kerja sebesar 2.33. Nilai ini akan dibandingkan dengan nilai ttabel pada tabel distribusi t. Dengan $\alpha=0,05, d f(33-2-1)=30$, diperoleh nilai $t_{\text {tabe }} l$ untuk pengujian dua pihak sebesar $\pm 2,042$. Dari nilai nilai diatas terlihat bahwa nilai thitung yang diperoleh 2.33), lebih besar dari ttabel $=2,042$, sesuai dengan kriteria pengujian hipotesis bahwa H0 dan H2 diterima, artinya secara parsial Perputaran Modal Kerja berpengaruh signifikan terhadap Return on Asset.

\subsection{Pembahasan}

\subsubsection{Pengaruh Likuiditas (Quick Ratio) terhadap Return on Asset}

Hasil penelitian menunjukan bahwa nilai korelasi secara parsial Quick Ratio berpengaruh signifikan terhadap Return On Asset. Quick Ratio memiliki hubungan dengan Rerturn On Asset dengan arah negative. Nilai korelasi negatif menunjukkan bahwa hubungan yang terjadi diantara keduanya adalah tidak searah, artinya semakin besar Quick Ratio maka semakin kecil Return On Asset begitu pula sebaliknya, semakin kecil Quick Ratio maka semakin besar Return On Asset.
Hal ini sejalan dengan teori yang dikemukakan oleh Syamsuddin (2011:209) yang menyatakan bahwa "Bilamana rasio likuiditas (quick ratio) meningkat maka baik profitabilitas (ROA) maupun resiko yang dihadapi akan menurun”. James C. Van Horne (2012:217) juga menyatakan bahwa kemampuan memperoleh laba (profitabilitas) berbanding terbalik dengan likuiditas. Maka dapat disimpulkan bahwa jika likuiditas dalam hal ini quick ratio dalam suatu perusahaan tinggi maka dapat dikatakan bahwa banyak modal kerja perusahaan yang menganggur, sehingga kemampuan perusahaan dalam memperoleh laba (profitabilitas) tidak maksimal.

Hasil dan Teori diatas dapat menjadi fenomena yang telah dikemukakan sebelumnya seperti yang terjadi pada perusahaan sub sektor logam yang memiliki Likuiditas dalam hal ini Quick Ratio rendah akan tetapi perusahaan tersebut menghasilkan Profitabilitas dalam hal ini Return On Asset rendah pula. Fenomena tersebut bertentangan dengan teori yang dikemukakan oleh para ahli yaitu ketika likuiditas (quick ratio) mengalami penurunan maka profitabilitas (return on asset) seharusnya mengalami peningkatan.

Hal ini sesuai dengan penelitian sebelumnya yang di kemukakan oleh Yunita Natalia, Ventje dan Harijanto (2014) yang menyatakan bahwa likuditas secara parsial berpengaruh signifikan negatif terhadap profitabilitas, artinya semakin tinggi likuiditas suatu perusahaan akan menurunkan profitabilitas. Hasil penelitian tersebut sesuai dengan teori yang dikemukakan oleh Syamsuddin (2011:209) likuiditas yang tinggi diakibatkan oleh banyaknya dana yang menganggur artinya kemampuan perusahaan untuk mengubah aktiva 
lancar menjadi uang kas rendah sehingga profitabilitas perusahaan akan menurun.

\subsubsection{Pengaruh Perputaran Modal Kerja terhadap Return on Asset}

Berdasarkan hasil uji hipotesis menunjukan bahwa Perputaran Modal Kerja mempunyai pengaruh signifikan terhadap variabel Return On Asset. Perputaran Modal Kerja memiliki hubungan arah yang positif dengan Return On Asset yang artinya semakin besar Perputaran Modal Kerja maka Return On Asset juga akan meningkat.

Hal ini sesuai dengan teori yang dikemukakan oleh Munawir (2010:80) menyatakan bahwa rasio perputaran modal kerja menunjukkan hubungan antara modal kerja dengan penjualan. Faktor modal kerja mempengaruhi tinggi rendahnya profitabilitas, artinya semakin cepat modal kerja berputar maka semakin banyak laba yang dihasilkan oleh perusahaan. semakin pendek periode perputaran modal kerja, semakin cepat perputarannya sehingga perputaran modal kerja semakin tinggi dan perusahaan semakin efisien yang pada akhirnya profitabilitas (ROA) semakin meningkat (Husnan, 2002:98).

Hasil dan teori diatas dapat menjawab fenomena yang terjadi pada perusahaan sub sektor logam yang telah dikemukakan sebelumnya yaitu pada saat Perputaran Modal Kerja meningkat akan tetapi Return On Asset yang dihasilkan mengalami penurunan. Fenomena tersebut bertentangan dengan teori-teori yang dikemukakan oleh para ahli, ketika Perputaran Modal Kerja meningkat maka seharusnya Return On Asset juga mengalami peningkatan. Sedangkan fenomena tersebut menunjukan hal yang sebaliknya atau adanya hubungan yang negatif, namun setelah dilakukan penelitian dengan menggunakan bantuan aplikasi SPSS dapat dibuktikan bahwa Perputaran Modal Kerja memiliki hubungan yang positif dengan Return On Asset, artinya apabila Perputaran Modal Kerja mengalami peningkatan maka secara otomatis Return On Asset juga akan mengalami peningkatan.

Hal ini sejalan dengan penelitianpenelitian sebelumnya seperti yang dikemukakan oleh Mulatsih (2014) dan penelitian yang dilakukan oleh Bagus Mangdahita (2016), yang menyatakan bahwa terdapat pengaruh positif dan signifikan secara bersamasama atau simultan dari perputaran modal kerja dan likuiditas (current ratio) terhadap profitabilitas (return on asset).

\section{KESIMPULAN DAN SARAN}

\section{$2.6 \quad$ Kesimpulan}

Berdasarkan hasil analisis dan pembahasan pada bab sebelumnya, maka penulis mengambil beberapa kesimpulan sesuai rumusan masalah yang dicari yaitu sebagai berikut:

1. Likuiditas (Quick Ratio) memiliki pengaruh negatif dan signifikan terhadap Return On Asset (ROA) pada perusahaan sub sektor logam yang terdaftar di Bursa Efek Indonesia periode 2011-2015 dengan besarnya pengaruh yang masuk kategori rendah. Hal ini menunjukkan ketika Quick Ratio perusahaan meningkat maka Return On Asset yang dibagikan perusahaan akan menurun. Menurunnya Return On Asset disebabkan karena perusahaan memiliki modal kerja yang menganggur dalam jumlah besar, 

2015) (Utami Prihati Ning Tias, Arni Purwanti, Surtikanti )

pemanfaatan modal kerja tersebut tidak dikelola secara efektif dan efisien sehingga perusahaan tidak dapat menghasilkan laba secara maksimal.

2. Perputaran Modal Kerja memiliki pengaruh positif signifikan terhadap Return On Asset (ROA) pada perusahaan sub sektor logam yang terdaftar di Bursa Efek Indonesia Periode 2011-2015 dengan besarnya pengaruh masuk kategori rendah. Hal ini berarti apabila Perputaran Modal Kerja perusahaan meningkat maka Return On Asset perusahaan akan meningkat. Meningkatnya Return On Asset dikarenakan singkatnya waktu perputaran modal kerja dan cepatnya perputaran modal kerja tersebut.

\subsection{Saran}

\subsubsection{Saran Operasional}

Berdasarkan kesimpulan yang telah dikemukakan diatas, maka saran yang dapat peneliti berikan bagi emiten dan investor antara lain sebagai berikut:

1. Agar Likuiditas Quick Ratio dapat meningkatkan Return On Asset maka perusahaan harus mampu memaksimalkan pengalokasian dana yang menganggur pada peningkatan produktivitas perusahaan seperti melakukan investasi jangka pendek sehingga perusahaan mampu meningkatkan keuntungan sehingga perusahaan dapat menghasilkan laba yang maksimal dari dana yang menganggur atau tidak produktif sehingga perusahaan mampu mengalokasikan dana untuk memenuhi kewajiban dari pengalokasian dana untuk memenuhi kewajiban dan dari keuntungan investasi jangka pendek yang dilakukan perusahaan.
2. Agar Perputaran Modal Kerja dapat meningkatkan Return On Asset maka perusahaan perlu melakukan upaya atau kebijakan yang secara umum agar perusahaan dapat mengelola aktiva lancar atau persediaan yang dimiliki perusahaan secara efektif untuk meningkatkan penjualan, sehingga terjadi peningkatan aliran dana dari kas operasi perusahaan.

\subsubsection{Saran Akademis}

\section{Bagi Perkembangan Ilmu}

Berdasarkan hasil penelitian, maka peneliti memberikan saran yang dapat dijadikan masukan bagi perkembangan ilmu yaitu sebagai berikut:

Penelitian ini diharapkan dapat memberikan tambahan pengetahuan tentang teori akuntansi keuangan, sebagai sumber informasi dan sebagai sumbangan pemikiran dalam mengembangkan disiplin ilmu akuntansi.

\section{Bagi Peneliti Selanjutnya}

Berdasarkan hasil penelitian, maka peneliti memberikan saran yang dapat dijadikan masukan bagi peneliti selanjutnya diharapkan untuk melakukan penelitian lanjutan dengan memperluas periode sampel, dan data penelitian agar dapat diketahui apakah hasilnya akan sama atau tidak. Dan juga disarankan menggunakan variable lain selain variabel Likuiditas (Quick Ratio) dan Perputaran Modal Kerja sebagai variabel yang mempengaruhi Return On Assets. Karena dalam penelitian ini 
ditemukan pengaruh dari variabel lain yang tidak diteliti dalam penelitian ini yang juga mempengaruhi Return On Assets.

\section{DAFTAR PUSTAKA}

Bambang Riyanto. 2011. Dasar-dasar Pembelanjaan Perusahaan. Edisi Keempat, Cetakan Kesebelas. Yogyakarta: BPFE Universitas Gadjah Mada.

Bagus Mangdahita Sariyana, Fridayana Yudiaatmaja, I Wayan Suwendra. 2016. Perputaran Modal Kerja Dan Likuiditas Terhadap Profitabilitas (Studi Pada Perusahaan Food And Beverages). e-Journal Bisma Universitas Pendidikan Ganesha (Volume 4).

Danang Sunyoto. 2013. Metodologi Penelitian Akuntansi. Jakarta : Aditama.

Harahap, Sofyan Syafri. 2011. Analisis Kritis Atas Laporan Keuangan. Jakarta : Raja Grafindo Persada.

Horne, James C. Van John M. Wachowicz, Jr. 2012. PrinsipPrinsip Manajemen Keuangan, Edisi Ketigabelas, Buku Satu, Alih Bahasa. Jakarta: Salemba Empat.

Husein Umar. 2011. Metode Penelitian Untuk Skripsi dan Tesis Bisnis. Jakarta : Rajawali.

Husnan, Suad. 2016. Manajemen Keuangan Cetakan I. Jakarta : UT

Imam Ghozali. 2011. Aplikasi Analisis Multivariate Dengan Program SPSS. Semarang : BP Undip.

Jumingan. 2014. Analisis Laporan Keuangan.Jakarta: Bumi Aksara

Kamalia Sani \& Maftukhatusolikhah. 2015. Pengaruh Capital Adequacy (CAR) Dan Quick Ratio (QR) terhadap Return On Asset (ROA)
Pada Bank Umum Syariah Di Indonesia 2011-2013.I-Economics Journal, Vol. 1, No. 1, hal. 6.

Kasmir. 2016. Analisis Laporan Keuangan, Jakarta : Rajawali Pers.

Mulatsih. 2014. Analisis Tingkat Perputaran Persediaan, Tingkat Perputaran Piutang, Tingkat Perputaran Modal Kerja Dan Tingkat Perputaran Kas Terhadap Profitabilitas Pada Perusahaan Sektor Kimia Di Bursa Efek Indonesia 2010-2012. Jurnal Ekonomi Bisnis (Volume 19 No. 13 Tahun 2014)

Munawir. 2014. Analisis Laporan Keuangan. Yogyakarta: Liberty.

Putri Handayani. 2007. Hubungan Likuiditas Terhadap Profitabilitas Pada PT. Pertamina (Persero) Unit Pemasaran I Medan.

Sugiyono. 2013. Metode Penelitian Kuantitatif Kualitatif dan $R \& D$. Bandung: CV. Alfabeta.

Sugiyono. 2017. Metode Penelitian Kuantitatif Kualitatif dan $R \& D$, Cetakan Ke-25. Bandung: CV. Alfabeta.

Syamsuddin Lukman. 2011. Manajemen Keuangan Perusahaan: Konsep Aplikasi Dalam Perencanaan, Pengawasan, dan Pengambilan Keputusan, Edisi Baru, Cetakan Kesebelas. Jakarta: Rajawali Pers.

Tambunan, Andy Porman. 2008. Menilai Harga Wajar Saham. Alex Media Komputindo. 